1981

\title{
Suppression of Popular Gatherings in England, $1800-1830$
}

Frank W. Munger

New York Law School, frank.munger@nyls.edu

Follow this and additional works at: https://digitalcommons.nyls.edu/fac_articles_chapters Part of the Judges Commons, and the Law and Society Commons

\section{Recommended Citation}

25 Am. J. Legal Hist. 111 (1981)

This Article is brought to you for free and open access by the Faculty Scholarship at DigitalCommons@NYLS. It has been accepted for inclusion in Articles \& Chapters by an authorized administrator of DigitalCommons@NYLS. 


\title{
Suppression of Popular Gatherings in England, 1800-1830
}

\author{
by Frank MUNGER*
}

Recent works on crime and society in eighteenth century England have reported challenging questions about the exercise of legal authority and the maintenance of control over the working classes. ${ }^{1}$ It has been suggested, for example, that the manipulation of sentencing for capital offenses at eighteenth century assizes reflected a deep concern for maintaining the legitimacy of class rule through the legal system apart from any immediate concern with crime. ${ }^{2}$ It has also been argued that while the creation of capital offenses under the Black Act of 1722 reflected class struggle over the uses of property, the commitment of the English legal system to even-handed justice tempered the effect of the Act in certain instances. ${ }^{3}$ Thus, by two different routes, recent historians have argued that the English criminal justice system produced more temperate and "just" results than the context of class rule might suggest.

Such studies suggest that a legal system, and specifically the legal system of Industrial Revolution England, was a complex system. While in principle legal authorities were committed to intentional, rational social control, complex constraints governed the range of choices they could exercise and many actually have shaped outcomes in quite a different way from the intentions of those enact-

\footnotetext{
* Attorney/Professor of Law, Antioch School of Law, Washington, D. C.
}

1. E. P. Thompson, Whigs and Hunters: The Origins of the Black Act (New York: Random House, 1975); D. Hay, et al., Albion's Fatal Tree: Crime and Society in Eighteenth Century England (New York: Random House, 1975). In addition, a growing literature on class relations in England provides background for the discussion of the legal system. E. P. Thompson, The Making of the English Working Class (London: Gollancz, 1965); J. O. Foster, Class Struggle In the Industrial Revolution: Early Industrial Capitalism in Three English Towns (London: Weidenfeld and Nicolson, 1974); R. Quinault and J. Stevenson, Popular Protest and Public Order, c. 1830-1870 (New York: St. Martins, 1974).

2. D. Hay, "Property, Authority and the Criminal Law," in Hay, et al., Albion's Fatal Tree, pp. 17-63.

3. E. P. Thompson, The Black Act, pp. 258-269. 
ing a law or announcing it in a decision. This study carries on the investigation of English criminal justice by exploring the influence of factors within and outside the legal system in late eighteenth century and early nineteenth century England. This article presents a case study of management of protests, strikes, demonstrations and other contentious public gatherings in the county of Lancashire during the Industrial Revolution. It examines the proportion of all gatherings which were suppressed by authorities during a thirty year period by location, size, objectives of participants, and form of the gatherings. The principal question addressed is what determined which gatherings were suppressed by authorities? The suppression of gatherings presented quite a different problem for authorities from the handling of sentencing at assizes or prosecutions under the Black Act. Within the limits permitted by these data, therefore, this article also looks at the extent to which suppression of gatherings under the criminal law was manipulated to preserve class interests and the extent to which suppression was constrained by the structure or ideology of the legal system itself.

\section{The Lancashire Quarter Sessions On the Eve of the Industrial Revolution}

The history of executive, legislative and judicial administration of the English county is the history of the quarter sessions and of the Justices of the Peace. Under statutes dating back to the reign of Edward III, the Justices of the Peace bore the chief responsibility for enforcement of law in the English county. ${ }^{4}$ In the eighteenth century, as a formal matter the quarter sessions of the English county was a court of general criminal jurisdiction, empowered to try all crimes with the exception of capital offenses and a few serious noncapital crimes reserved for the courts of the Assize. In addition to their jurisdiction over crimes, the Justices were charged with a variety of administrative responsibilities. Among these responsibilities was the suppression of riots, public violence, and illegal gatherings and other public disturbances. Further as substantial landholders and leading citizens, Justices combined personal social status and political influence with legal authority. The combination, together with the acquiescence of central government for most of the eighteenth century in their assumption of general responsibility for peace keeping and administration of the counties, gave the Justices near-legislative authority, particularly in the handling of disturbances.

4. Esther Moir, The Justice of the Peace (Harmondsworth, Middlesex: Penguin, 1969), p. 18; W. S. Holdsworth, A History of English Law, 6th ed. rev., 12 vols. (London: Methuen, 1938): 1: 288-291. 
The laws governing public gatherings which were administered by the Justices of the Peace prior to the French Revolution included the Riot Act, the common law of unlawful assembly and riot, the eighteenth century acts forbidding combinations of workers in specific trades, the common law of conspiracy, ${ }^{5}$ and a variety of statutes forbidding specific types of gatherings such as the Sunday Observance Act. $^{6}$ This legal arsenal gave the justices broad discretionary powers to suppress gatherings. The Riot Act, for example, authorized dispersal of any gathering of twelve or more persons in the process of commiting a breach of the peace. Of course, deciding what was breach of the peace was left to the Justices enforcing the law. ${ }^{7}$ The Riot Act permitted Justices (or another official authorized to employ the Act) to use deadly force if a gathering did not disperse within one hour of the reading of the statutory proclamation specified in the Act. Few participants were likely to take such a risk for the sake of challenging the Justice's decision to read the proclamation under particular conditions. Because the Justices also supervised the police, and tried persons apprehended for violation of nearly all the laws, their power to intimidate and harrass was even greater than these statutes alone imply. The same Justice who con-

5. The Riot Act, 1 Geo. I, st. 2 , c. 5 (1714), was the most frequently relied upon authority for repression of public disturbances. Its procedures were simple, requiring the reading of a statutory proclamation by a J. P., and it often enabled a Justice of the Peace to avoid violent confrontation with a crowd since lethal force was permitted against any who remained one hour after the reading of the proclamation. To suppress collective action by workers the Justices could apply the statutory prohibitions against combinations in particular trades. These were the product of Parliamentary acceptance of the principles of political economy in which the Industrial Revolution was rooted. Statutes prohibited combinations among the woollen workers (1725), hatters (1749), clothiers (1775), silk weavers (1777), paper makers and related trades (1795), and millwrights (1799-this act was converted by Parliament into the first general combination act.) As hostility to combinations of workers grew, quarter sessions found a much more potent weapon than the combination acts, which limited penalties to three months in the house of correction. Wright describes the creation of the common law crime of labor conspiracy as the "growth of a crime at common law by reflection from statutes." Wright, The Law of Criminal Conspiracies (Philadelphia: Blackstone, 1887), p. 44. The penalties exacted amounted to years in prison, not months as under the statutes.

6. 21 Geo. III, c.49 (1981).

7. The Riot Act and the law of unlawful assembly provided a particularly flexible basis for exercising authority over gatherings. There was no appeal to a higher authority between the reading of the Riot Act proclamation and the end of the hour after which the troops or militia could open fire.

The law of constructive treason provided another source of discretionary authority over gatherings. A gathering which disturbed the peace for a purpose which was interpreted as "public" in the sense of correcting a public evil, such as a riot to destroy all brothels or all dissenters' meeting houses, could be construed as an assault on the perogative of the state to handle such matters. As such it was a form of treason and thus punishable by death. See for example R.v. Dammaree, 15 St.Tr. 522 (1910). 
victed at petty sessions and sentenced at quarter sessions also directed troops and constables to make arrests (perhaps leading them himself) and was responsible for licensing publicans, approving the rules of friendly societies, and licensing dissenters' meeting places. ${ }^{8}$ All of these powers could at times be used to intimidate and suppress trade unions, political associations, or any other form of collective action.

While on the one hand the Justices were granted broad legal authority to suppress popular gatherings, and there appear to have been few effective mechanisms for restraining abuses of that power, on the other England as yet had few police other than the Justices themselves and the militia or military if they happened to be available. There were, therefore, practical constraints on the exercise of the Justices' broad powers. The combination of broad authority and limited resources may have contributed to the accomodation of collective action by the Justices of the Peace in Lancashire in the eighteenth century. Justices by no means attempted to suppress every form of collective action to the extent permitted by law. For example, a Manchester Justice provided legal support to a combination of check weavers attempting to enforce apprenticeship statutes until he was overruled by Lord Mansfield at the Lancaster Assizes in $1758 .{ }^{9}$ In 1780 , rather than risk casualties, the Justices of southeast Lancashire published rules to govern the reading of the Riot Act in anticipation of gatherings by striking textile workers. ${ }^{10}$ In 1800 , a Justice of the Peace at Ashton under Lyne ordered constables to assist in the sale of potatoes at less than market price to appease

8. As the scope of their responsibilities grew, so did their control of policing. In the late eighteenth and early nineteenth centuries, by statute, Justices of the Peace directed the activities of constables (two for each township in the county of Lancashire) two elected by the court Leet of each manor. H. B. Simpson, "The Office of Constable," English Historical Review 10 (August, 1895): 625-641. By statute Justices could call on the militia of the county for assistance. C. M. Clode, Military Forces of the Crown, 2 vols. (London: J. Murray, 1867): 1: 40,311, 328. By custom, and by decision of the Home Office, the regular military stationed in the vicinity of disturbances were to respect the orders of the Justices of the Peace. See for example Portland (Home Secretary) to Commander Heathcote, 30 September, 1800. H.O. 42/12/184-5. The Justices could also call on private citizens to assist in the apprehension of felons and the suppression of disturbances. Holdsworth, A History of English Law, 8: 329, Leon Radzinowicz, A History of English Criminal Law and lts Administration, 4 vols. (London: Stevens and Sons, 1968): 4: 107; 13 \& 14 Car. 2, C.12, s.15. See also the Watch and Ward Act of 1812 which authorized drafting citizens to serve as special constables. 52 Geo. 3, c.17. They also granted licenses to alehouse keepers, licensed friendly societies (after 1793), licensed dissenters' meeting places (after 1812), and for substantial periods between 1794 and 1825 were empowered to deny licenses to public meetings to discuss grievances.

9. A. P. Wadsworth and J. De L. Mann, The Cotton Trade and the Rise of Indus. trial Lancashire 1600-1780 (Manchester: Manchester University Press, 1931), p. 364.

10. Ibid., p. 373. 
women who had attempted to seize and sell them to protest a sudden rise in price. ${ }^{11}$ Although there are few studies of the management of collective action in the eighteenth century, there is evidence that such examples of leniency are not uncommon. ${ }^{12}$

Thus policing of gatherings may have been affected by the fact that the Justices were constrained by limited resorces. Moreover, even bitter protest tended to be relatively short-lived, and interpretable as a reaction to temporarily oppressive conditions which the Justices could freely deplore. Food riots, collective action against employers and other forms of gathering could frequently be viewed as defending the traditional order of things, of which Justices of the Peace were a part. Hence, leniency was consistent with the Justices' paternalistic authority. The Justices of the Peace threatened the use of force but frequently yielded to sympathy and lenient treatment, with the effect that respect for the Justices increased.

But the conditions of the eighteenth century which explain leniency in crowd management did not persist as the Industrial Revolution progressed. Major changes in the social and economic order of late eighteenth and early nineteenth century Lancashire had an impact on the character of public gatherings. We turn next to a discription of these changes. The data on the suppression of popular public gatherings in Lancashire which appear in later sections describe the way in which the Industrial Revolution affected the management of gatherings. After examining these data we will return to the question of whether or not the same patterns of leniency persisted in a period with very different characteristics.

\section{Contentious Popular Gatherings in}

Industrial Revolution Lancashire

The rise of the textile industry in Lancashire after 1780 was accompanied by massive changes in the economic and social order of the county. ${ }^{13}$ The opportunities for contentious gatherings and the issues which drew participants changed with the rise of a capitalist order and the redistribution of the population in new locations and occupations. The political environment created by the French Revo-

11. Manchester Mercury, June 17, 1800.

12. See, for example W. J. Shelton, English Hunger and Industrial Disorder (London: Macmillan, 1973) especially Chapter Two.

13. See generally, E. Lipson, The Economic History of England, 3 Vols (London: Black, 1913); L. W. Moffitt, England on the Eve of the Industrial Revolution: A Study of Economic and Social Conditions from 1740-1760 (New York: Barnes and Noble, 1964); A. J. P. Taylor, "Concentration and Specialization in the Lancashire Cotton Industry, 1825-1850," English Historical Review, 2d ser, 1 (March, 1949): 114-122. 
lution in 1789 also had an impact on the character of gatherings, their objectives and participants.

The entrenchment of a capitalist order in Lancashire began with the transformation of the textile industry and was rapidly felt in the distribution of work sites and the location of the population. In 1750 Lancashire was still predominantly an agricultural region with few established crafts and a slowly growing cottage textile industry. ${ }^{14}$ Over the next half century Lancashire's demography changed radically. Southeastern Lancashire working class villages grew rapidly, tripling or quadruping in size between 1750 and 1800 . Not only was the working class population disproportionately concentrated in one region of the county after mid-century but the locus of work and the focus of public gatherings tended to become decidedly more urban as worksites became centralized.

The demographic restructuring of the county of Lancashire was one major effect of the Industrial Revolution. Another closely related effect was the reorganization of work. Long before the rapid rise in the number of textile workers in the county the changing means of producing textiles and related products had an impact on the daily work routine and on every aspect of daily life dependent on work. ${ }^{15}$ A major theme of collective action 1790 was control of the means of making a living, whether the specific focus was on apprenticeship, increasing wages, or resistence to cuts in wages. The persistence of collective action by workers seeking a place in a reorganized economy gave contentious gatherings a new militancy. It was no longer possible for an observer to claim that popular protest was a short term response to a temporary dislocation of prices or supply of food or an occasional slump in trade.

A third source of change in contentious gatherings was the consciousness among the working classes of political oppression. Articulation of political oppression and the need for political reform by the working classes followed in the wake of the French Revolution. The revolutionary ideology found its enthusiastic supporters both among persons with social standing as well as among the working classes. In 1791 Bastille Day was celebrated by parliamentary reformers throughout Lancashire. ${ }^{16}$ In 1792 a radical newspaper appeared in the county, and the Boroughreeve elected for the court leet of the Manor of Manchester was a Radical. ${ }^{17}$ This surge of

14. Moffitt, England on the Eve of the Industrial Revolution, pp. $68 \mathrm{ff}$.

15. D. Bythell, The Handloom Weavers (Cambridge: Cambridge University Press, 1968), especially Chapter One; N. Smelser, Social Change in the Industrial Revolution; An Application of Theory to the British Cotton Industry (Chicago: University of Chicago Press, 1959).

16. Bayley to Home Office, July 19, 1791. H. O. 42/19.

17. L. S. Marshall, The Development of Public Opinion in Manchester 1780-1820 (Syracuse: Syracuse University Press, 1946). pp. 126ff. 
interest in political reform brought repression after the beginning of the war with France in 1793. The effect of this suppression was to drive persons of property and social standing from the ranks of the reformers leaving, for a time, working class organizations for political reform on their own. But by 1799 the better known working class organizations for political reform had been outlawed by act of parliament and their members driven underground. ${ }^{18}$ The political reaction included suppression of nearly every other form of working class organization or collective activity as well. Acts of Parliament made Friendly Societies subject to judicial supervision, made all meetings to discuss grievances licensable by Justice of the Peace and outlawed all combinations of workers. ${ }^{19}$ The hostility which these enactments engendered gave focus to the class conflict which economic changes in Lancashire and throughout England had created. The importance of unions and of political organizations could not have been made clearer. Both increased steadily in numbers after 1800 , many as secret working class organizations. ${ }^{20}$

In sum, the increase and concentration of population, the new organization of work, and the political unrest which began after the French Revolution produced changes in the participants, forms and objectives of contentious gatherings. The number of gatherings increased. The largest gatherings were increasingly larger. The objectives of typical contentious gatherings shifted from food supply and a defense of the traditional community to struggles with employers over major changes in working conditions, opposition to government, economic policies and political reform. Participants in gatherings were increasingly likely to be recruited by a focused association or organizaiton rather than from among neighbors or workers in close daily contact. These changes gave contentious gatherings a new appearance and a new militancy.

\section{The Suppression of Contentious Public Gatherings in Nineteenth Century Lancashire}

Each of the changes which affected the form, issues, and number of participants in public gatherings also had an independent effect on the world of the Justices of the Peace. Capitalism brought political challenge to the rural elite from the commercial classes. Increases in numbers and concentration of residents in industrializing parts of Lancashire further strained the inadequate administra-

18. 39 Geo. III c.79.

19. 33 Geo. II c.54 (Friendly Societies); 36 Geo. II c. 8 (Seditious Meetings); 39 \& $40 \mathrm{Geo}$. III c. 106 (Combinations).

20. E. P. Thompson, The Making of the English Working Class, pp. $472 \mathrm{ff}$. 
tive structure of the county. The war with France brought fears of revolution. Together the changes in public gatherings and the changing pressures on the Justices of the Peace created a very different context for suppression of contentious gatherings from pre-war eighteenth century Lancashire. In this section and the next the findings of an empirical study of the suppression of contentious gatherings in Lancashire between 1800 and 1830 are described. The purpose of the research was to produce reliable estimates of the number and type of contentious gatherings in Lancashire and to estimate the rate at which each type was suppressed. Since few previous attempts have been made to obtain accurate measurements of this type to aid description or theory formulation the methods of the study will be briefly set forth before reviewing the findings.

Describing and explaining patterns of response to public gatherings presents problems of measurement familiar to the historian of crime trends. ${ }^{21}$ Official data about crime reflect the status of the policing apparatus as much as the "true" rate of crime. Similarly, reliance on the Home Office Papers and the official records of the Lancashire Quarter Sessions for information about gatherings would limit our attention to those gatherings which drew the attention of authorities. We could learn little about why particular gatherings were suppressed. To estimate a true rate of occurrence or a rate of repression it is necessary to have an estimate of the number of gatherings which is independent of the accounts of authorities.

Two samples of public gatherings were created using three Lancashire county newspapers and the Home Office Papers as well as a variety of secondary sources for the period between 1800 and 1830 . The Home Office Papers used for the study consisted of correspondence between Justices of the Peace and the Home Office. Every public gathering mentioned in the newspapers between 1800 and 1830 in which a claim was manifested against another group, organization or institution and involving a minimum of five persons was included in the first sample. Strikes were enumerated separately. The second sample was created by ransacking the newspapers, Home Office Papers and secondary sources for gatherings and strikes in nine selected years: $1800,1801,1805,1806,1810,1812$, 1818,1830 . For the nine years in the second sample, public gatherings of all descriptions were included whether or not they were contentious, i.e. manifested a claim, and the events were sorted later

21. Albert J. Reiss, "Measurement of the Nature and Amount of Crime," Studies in Crime and Law Enforcement in Major Metropolitan Areas; A Report to the President's Commission on Law Enforcement and Administration of Justice (Washington, D. C.: U.S. Government Printing Office, 1967), pp. 1-83. C. Tilly, A. Levett, A. Q. Lodhi, F. Munger, "How Policing Affected the Visibility of Crime in Nineteenth Century Europe and America," Working Paper of the Center for Research on Social Organization, \#93, Ann Arbor, Michigan, 1974. 
by computer. Data for each event in both samples were assembled, coded, key punched and placed on computer tape. For the years 1800 to 1830 , which are the basis of the research reported here, the first sample contained 473 gatherings where violence occurred, 245 strikes, and 123 gatherings with political objectives. These categories are not, of course, mutually exclusive. For the nine years for which a more intensive search was conducted, there were 938 public gatherings in the sample. These data combined with data on repression contained in the Home Office Papers and the Lancashire Quarter Sessions records permitted an accurate estimate of the rate of repression of gatherings. ${ }^{22}$

In the preceding section, significant changes in the overall appearance of contentious gatherings in the early nineteenth century were described, including their increasing size, militancy, and focus on political and economic problems. The sample of Lancashire events allows us to look at the relationship between each of these characteristics and the rate of repression of gatherings over time. For three types of collective action, collective violence, strikes and political meetings (with some overlap), Table 1 shows the number of events and the percent repressed by year. Collective violence was repressed at the highest overall rate. There is a pattern of slow increase in the number of violent gatherings, as we would expect due to the increased number of persons in the population. No trend in the rate of repression is apparent on the basis of visual examination of the table. The annual variations in the rate of repression are great enough to allow us to conclude that the policing of the county for violent events was influenced by other factors.

Strikes, as a form of collective action, were repressed about half of the time. Here, unlike the case of collective violence, a trend over time can be observed. Repression of strikes by authorities declined after 1825 . The rate before 1825 was $58 \%$, but after 1825 it dropped to about $30 \%$. The law was liberalized in 1824 and 1825 ; nevertheless, the rate of repression shows that strikes and combinations of workers were the target of considerable activity by authorities even after 1825. Public gatherings with political objectives were repressed at a lower rate than either collective violence or strikes. Year to year variations were extreme. In five years $100 \%$ of the political meetings were repressed; in five other years, none was repressed. No trends over time are apparent. For two time periods; 1800-1801 and 18171819 , meetings to discuss political grievances which had not re-

22. By the rate of repression I will mean the proportion of gatherings of a given description which were the target of repression by authorities. Thus the repression need not have had a visible effect. In general, the manifest intention of authorities to make the particular collective action more costly or difficult to engage in combined with any action which authorities believe will accomplish that end is considered repression. 
TABLE 1

PERCENT EVENTS (N) REPRESSED ${ }^{a}$ IN LANCASHIRE, ENGLAND BY TYPE BY YEAR 1800-1830

\begin{tabular}{|c|c|c|c|}
\hline Year & $\begin{array}{l}\text { Collective } \\
\text { Violence }\end{array}$ & Strikes $^{b}$ & $\begin{array}{l}\text { Political } \\
\text { Gatherings }\end{array}$ \\
\hline 1800 & $16(13)$ & $0(1)$ & $0(1)$ \\
\hline 1801 & $59(12)$ & $100(2)$ & $20(10)$ \\
\hline 1802 & $100(3)$ & $100(4)$ & $*(0)$ \\
\hline 1803 & $50(5)$ & $42(7)$ & $*(0)$ \\
\hline 1804 & $100(1)$ & $100(2)$ & $100(1)$ \\
\hline 1805 & $50(2)$ & $67(3)$ & $*(0)$ \\
\hline 1806 & $50(4)$ & $*(0)$ & $100(1)$ \\
\hline 1807 & $84(6)$ & $0(1)$ & $0(2)$ \\
\hline 1808 & $89(28)$ & $74(19)$ & $100(1)$ \\
\hline 1809 & $50(8)$ & $100(4)$ & $0(2)$ \\
\hline 1810 & $78(22)$ & $67(6)$ & $100(2)$ \\
\hline 1811 & $0(2)$ & 0 (1) & $*(0)$ \\
\hline 1812 & $62(69)$ & $100(1)$ & $50(4)$ \\
\hline 1813 & $43(7)$ & $*(0)$ & $*(0)$ \\
\hline 1814 & $28(7)$ & $40(5)$ & $*(0)$ \\
\hline 1815 & $100(10)$ & $67(3)$ & $*(0)$ \\
\hline 1816 & $68(22)$ & $84(6)$ & $22(23)$ \\
\hline 1817 & $100(8)$ & $67(3)$ & $40(5)$ \\
\hline 1818 & $92(24)$ & $40(35)$ & $100(1)$ \\
\hline 1819 & $67(17)$ & $67(2)$ & $42(33)$ \\
\hline 1820 & $80(5)$ & $0(2)$ & $0(10)$ \\
\hline 1821 & $33(3)$ & $50(4)$ & $*(0)$ \\
\hline 1822 & $100(3)$ & $33(6)$ & $*(0)$ \\
\hline 1823 & $57(7)$ & $100(1)$ & $*(0)$ \\
\hline 1824 & $100(8)$ & $50(4)$ & $*(0)$ \\
\hline 1825 & $100(1)$ & $0(9)$ & $*(0)$ \\
\hline 1826 & $50(28)$ & $50(8)$ & $7(15)$ \\
\hline 1827 & $73(11)$ & $33(12)$ & $0(3)$ \\
\hline 1828 & $58(12)$ & $20(5)$ & $*(0)$ \\
\hline 1829 & $54(52)$ & 39 (17) & $0(1)$ \\
\hline 1830 & $71(56)$ & $37(55)$ & $11(9)$ \\
\hline $\begin{array}{l}\text { Average } \\
(\mathrm{N})\end{array}$ & $\begin{array}{c}67.5 \\
(456)\end{array}$ & $\begin{array}{l}52.6 \\
(214)\end{array}$ & $\begin{array}{l}38.4 \\
(123)\end{array}$ \\
\hline
\end{tabular}

* No events.

a-Percent events repressed by type $=$ Events Targeted by Authorities by Type Total Events in Sample by Type

$b$-Average before $1825=58.4$; after $=29.8$ 
ceived prior license from a Justice of the Peace or other official could be dispersed as if a riot had occurred. Yet the rate of repression for these periods is lower than the rate of repression of either violence or strikes, and lower than the rate of repression of political meetings in many other years when no Seditious Meetings Act was in force, for example 1812.

Turning to the nine years for which detailed information is available, comparisons are possible between the rates of repression of a wider variety of forms of collective action. Table 2 shows that collective violence was repressed at a higher rate than any other form of collective action over the nine years, although in particular years, other forms of collective action were repressed at a higher rate. In some years all forms of collective action were repressed at a higher rate regardless of the form or objective, for example in 1812 . Further there is a noticeable difference between the repression of meetings to draft petitions to Parliament and other peaceful forms of gathering which had as their objective some other means of manifesting a claim or grievance, namely "Peaceful Meetings" and "Contentious Demonstrations."

Proceeding one step further, we can compare the relative effects of violence and political objectives of the participants on the rate of repression. Table 3 shows the effects of political objectives on repression while separating out the effects of violence and also the size of the gathering. ${ }^{23}$ There is good reason to think that size alone might have been a factor influencing decisions to repress meetings, and we will turn to that factor next in our discussion. The analysis shows that in all time periods violence was a significant factor leading to arrests, as we would expect. However, opposition to government is positively correlated with arrrests in two periods, negatively correlated in another, and not significantly related to arrests in the remaining time periods. Hence, repression of nonviolent, political meetings among the working classes was not consistent. Yet the relationship is strong in some years while nonexistent in others, suggesting that some other key variable changed from year to year which affected the reactions of authorities to these gatherings.

Table 3 also raises questions about the relationship between the size of a gathering and repression. The changing demography of Lancashire meant that authorities were faced with gatherings of increasing size. There are reasons for thinking that great size by itself, other things being equal, might lead to repression. Apart from the reaction of authorities to the militancy of particular gatherings, there

23. Size is included at this point for the simple reason that larger crowds draw more attention. 


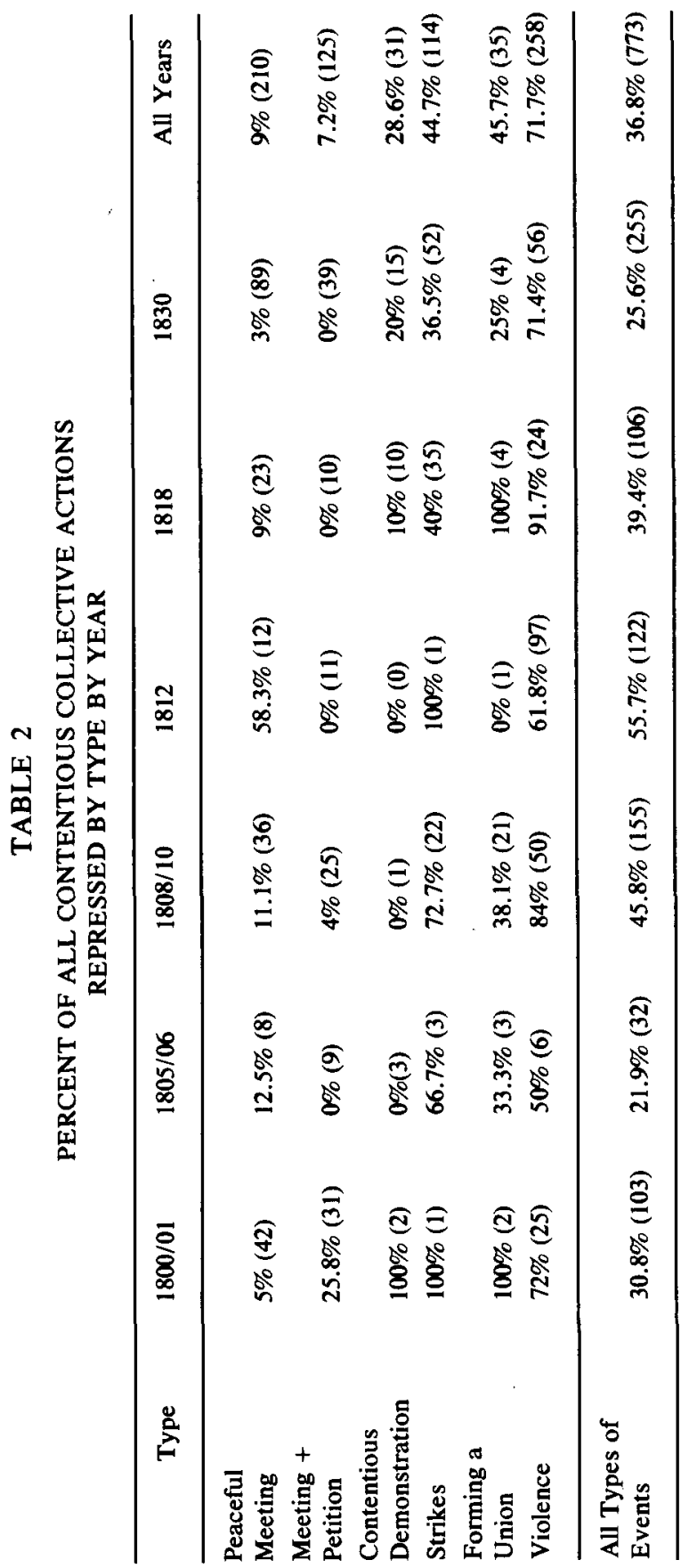


TABLE 3

STANDARDIZED REGRESSION OF ARRESTS ${ }^{a}$ (PER EVENT) ON NUMBER OF PARTICIPANTS, LEVEL OF VIOLENCE, AND LEVEL OF HOSTILITY TO AUTHORITIES BY YEAR

\begin{tabular}{ccccccr}
\hline $\begin{array}{l}\text { Equation } \\
\text { Number }\end{array}$ & Year & $\begin{array}{c}\text { Number of } \\
\text { Participants }\end{array}$ & $\begin{array}{c}\text { Level of } \\
\text { Violence }\end{array}$ & $\begin{array}{c}\text { Oppositionc } \\
\text { to Gov't }\end{array}$ & R $^{2}$ & N \\
\hline 1 & All & .04 & $.43^{*}$ & .03 & .18 & 554 \\
2 & $1800 / 1$ & $-.35^{*}$ & $.49^{*}$ & $.34^{*}$ & .35 & 79 \\
3 & $1805 / 06$ & $-.40^{*}$ & $.78^{*}$ & -.14 & .37 & 29 \\
4 & $1808 / 10$ & .21 & $.42^{*}$ & $-.20^{*}$ & .25 & 132 \\
5 & 1812 & .01 & $.26^{*}$ & $.42^{*}$ & .21 & 76 \\
6 & 1818 & .09 & $.57^{*}$ & -.01 & .34 & 63 \\
7 & 1830 & .05 & $.40^{*}$ & .02 & .16 & 175 \\
\hline
\end{tabular}

Starred $(*)$ coefficients are more than twice their standard error.

$a$-The square root of arrests and participants were used instead of raw scores to correct for skewed distribution.

$b$-Violence is measured as a three level ordinal variable:

$0=$ No violence; $1=$ Threats minor property damage, pushing, isolated fist fight; 2 = more violence than 1 .

c-Opposition to government means manifest hostility to authorities (beyond resistence to repression), or objectives involving a substantial change in the policies or form of government.

was a long term increase in their uneasiness about the masses of landless people in the "populous districts" of England..$^{24}$ The landless population was more difficult to control because of its transience and, it was supposed, its shiftlessness. ${ }^{25}$ Annual fairs were an early target of these fears, and quarter sessions across England in the latter part of the eighteenth century attempted to suppress them. ${ }^{26}$ Further, as residential patterns and gatherings urbanized there was simply less space in the larger towns for large gatherings to occur with a minimum of risk of disturbance to the principal inhabitants. We might expect, under such circumstances, a struggle

24. The sheer increase in numbers in the population and the breakdown of parish and township government is a theme which runs through the Parliamentary Papers of the 1830s when Parliament first began to look closely at the consequences of the changes brought about by the Industrial Revolution. See "Report of the Committee on Manufactures, Shipping and Commerce," Parliamentary Papers, 1833, VI, pp. 801 ff.

25. L. Radzinowicz, History of English Criminal Law and Its Administration, 4 vols. (London: Stevens, 1848-1968): 4: 17-18; R. Malcolmson, Popular Recreations in English Society, 1700-1850 (Cambridge: Cambridge University Press, 1975), p. 96.

26. S. Webb and B. Webb, The Parish and the County (Hamden, Conn.: Archon, 1963), pp. 528, 529, 536. 
for control of public spaces as well as a struggle for control of other community resources. Given the small, non-professional police forces of the eighteenth century, a sizeable gathering might present serious problems independently of the other factors creating official fears. Contrary to these expectations, however, Table 4 shows that size by itself did not govern the rate of repression. The largest gatherings in the sample (5000) have a slightly higher rate of repression than the next largest (950-5000). But small gatherings had higher rates of repression. With regard to the larger gatherings, authorities were evidently discriminating. Many large contentious gatherings were allowed to take place, unmolested. The higher rate of repression of small gatherings may be explained the fact that small gatherings might simply have been more manageable by a small police force and therefore easier to repress.

Because the police (Justices, constables or troops) were few in number and slow to mobilize, the location of an event should have had an effect on the rate of repression. An event subject to repression taking place in the countryside where there were no troops or constables would fare differently from an event taking place near a garrison in the more populous areas of the county, such as Bolton or Manchester or Liverpool. The hypothesis is that all other things being equal events which occurred nearer to places where Justices, constables or troops were located, or nearer to major community resources such as markets, factories or public buildings, were more likely to be repressed. Table 5 shows that on the whole, location did make a difference. An event at an urban industrial site was seventy percent more likely to be repressed than a gathering at a rural location away from factories and markets. In general, gatherings near factories and markets were much more likely to be repressed than gatherings which were not near such important community centers. Panel 2 shows that these relationships are not an effect of the form of the gathering. That is, the fact that urban events at an industrial site were repressed more often is not due to the fact that they were more violent than other events. They were more likely to be strikes, rather than some other form of gathering, and strikes were illegal for most of the sample period. However, gatherings at markets were also repressed at a higher rate independent of violence. Finally, panel 1 of Table 5 raises new complexities as well. There was considerable regional variation in the site-rate of repression, with gatherings taking place in the agricultural regions of Lancashire, namely the hundreds of Lonsdale, Blackburn and Amounderness which experienced a rate of repression only one third that of the rate of repression in the manufacturing districts near Manchester and Bolton. Gatherings in the vicinity of Ashton under Lyne, a populous and industrializing region with many textile workers, also experienced a relatively low rate of repression. 


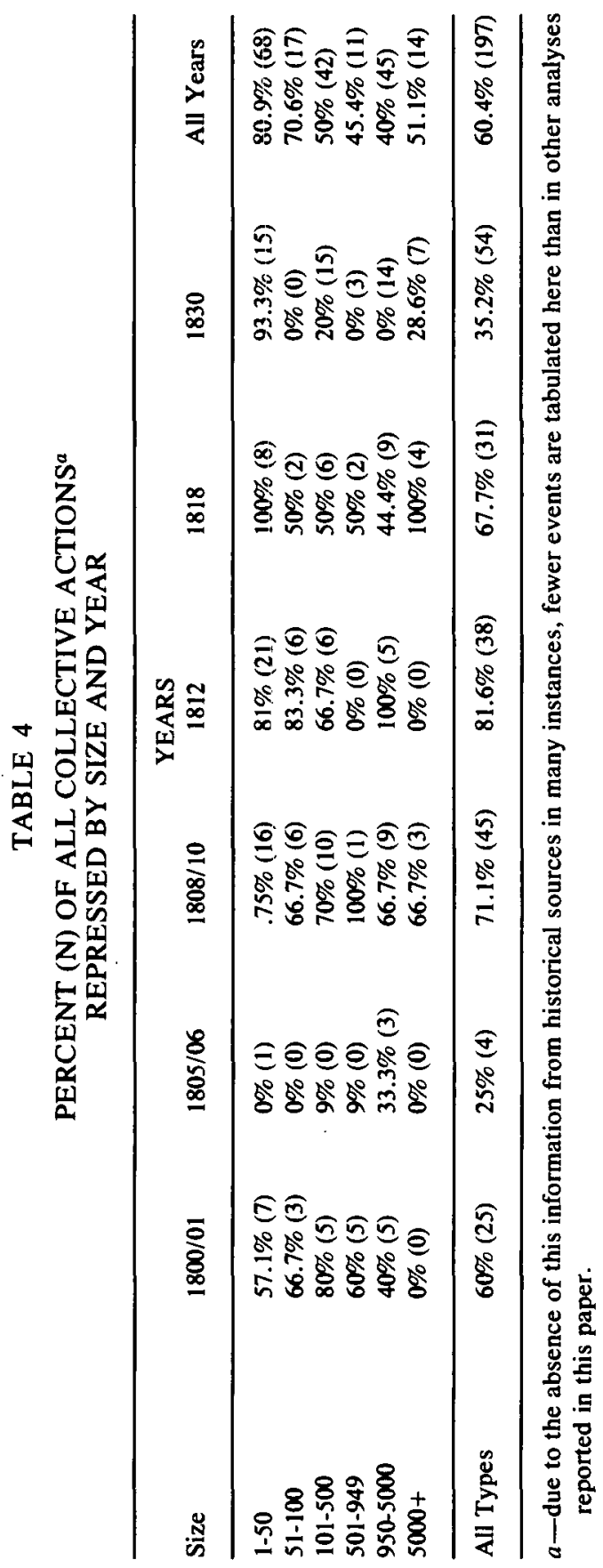




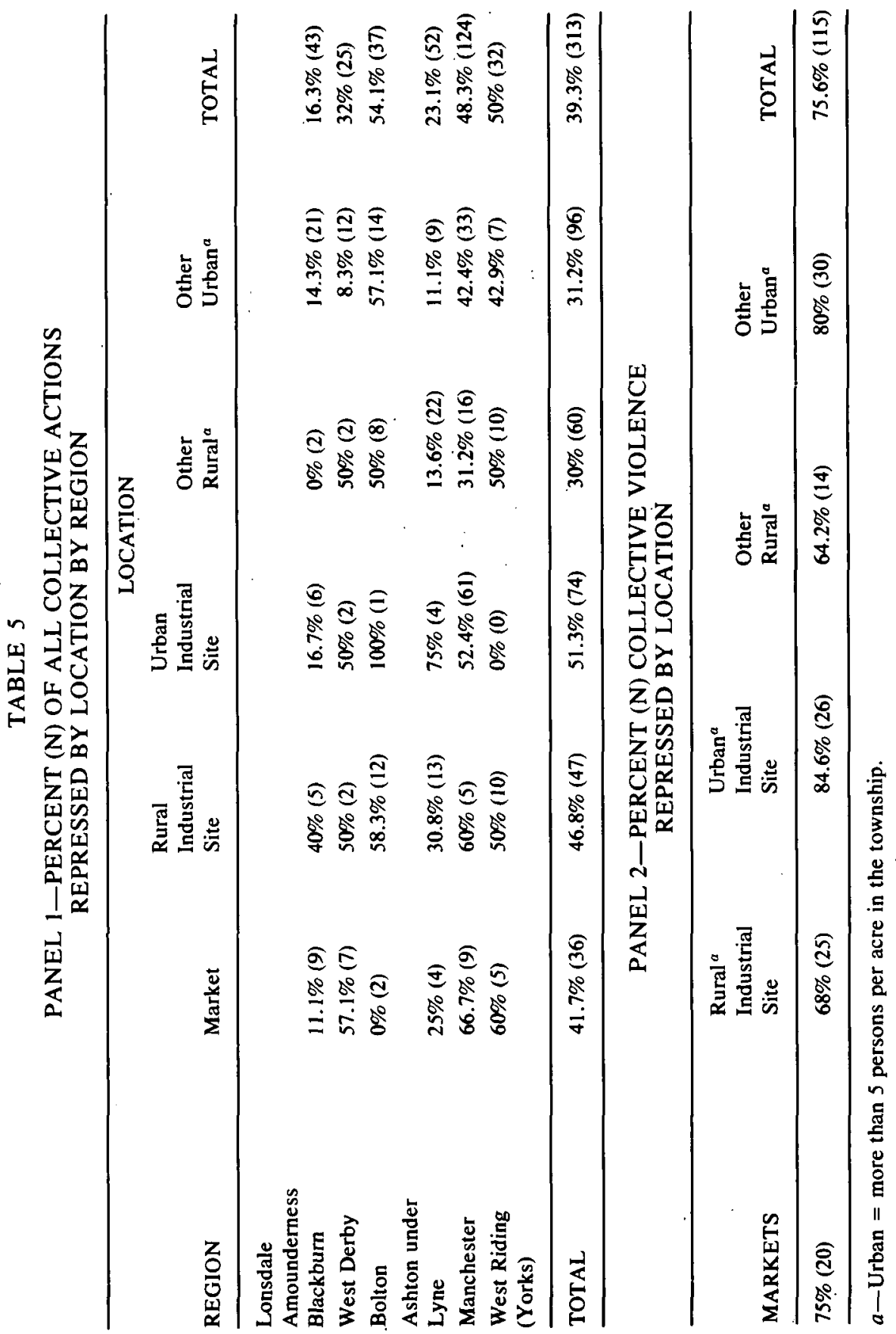


While there are many additional explanatory factors and combinations of factors which these data would allow us to explore, the results discussed so far have provided us with sufficient perplexities for us to stop and to assess what they have shown. The findings must be placed in perspective by relating the patterns of repression to the slow development of the policing apparatus of the county, the changing attitudes of the Justices of the Peace toward popular gatherings, and dramatic changes in ruling class consciousness brought about by both the war with France and the militancy of popular gatherings.

\section{Suppression of gatherings and the organization of policing}

The Lancashire data have revealed the unevenness of policing throughout the county and the period under study. Notwithstanding the authority possessed by Justices of the Peace to repress collective violence and the desire of the Home Office to have Justices of the Peace suppress violence the rate of repression varied greatly from year to year, from hundred to hundred, and on the average did not exceed two thirds of the known violent gatherings. This rate of repression illustrates a characteristic of all systems of policing. No system detects, let alone acts upon every event subject to sanction. ${ }^{27}$ The rate of repression reveals, in part, the limits imposed by the organization of the system for policing and how that system was adapted to the social system within which it operated.

The combined impact of population growth and industrial concentration during the Industrial Revolution on the work of the quarter sessions must have been enormous. But changes in organization were slow in coming. Approximately the same number of Justices of the Peace, constables and entrepreneurial police were available in 1820 as in $1750 .{ }^{28}$ The reluctance to adopt a more adequate means of county administration was not limited to Lancashire. Many quarter sessions in England organized specialized subcommittees from time to time to handle special problems, but administration by unpaid nonprofessionals without an adequate staff remained the rule throughout rural England until well into the nineteenth century. ${ }^{29}$ The Salford Division of the Lancashire Quarter Sessions was almost unique in the fact that in 1805 it applied to Parliament for authority to pay its chairman a salary.

27. See Note 21, supra.

28. E. C. Midwinter, Law and Order in Early Victorian Lancashire (York: St. Anthony's Press, 1968), passim.

29. See E. Moir, The Justice of the Peace (Harmondsworth: Penguin, 1969), Chapter Five. 
Manchester, the largest town and the commercial center of the region, also took some steps to improve its police administation. The manor of Manchester was presided over by an ancient court leet which appointed two titular constables and a paid deputy constable with up to twelve assistants who were the "day police" for the population of nearly 90,000 in the township in 1801 . In 1790 the township was granted an Improvement Act authorizing employment of night watchmen, but no additional day police. However, until Manchester became a borough in 1838 , the number of day police remained unchanged. In 1813 Manchester obtained Parliamentary approval for a paid magistrate to handle the day to day needs of the constables for assistance in processing persons arrested in the region around Manchester. ${ }^{30}$ While Manchester's spectacular growth was not matched by any other town in Lancashire the pattern was the same elsewhere. Yet no town or borough had more than a handful of day police. Between 1820 and 1830 a few Lancashire towns sought Parliamentary permission to increase the numbers of day police, Preston to ten, Ashton under Lyne to five or ten. ${ }^{31}$ But the principal period of growth of the professional police occurred after 1829 following the example of the Metropolis which acquired its first professional police force in that year.

The availability of Justices of the Peace was more critical than the availability of other types of authorities. An active Justice supervised constables, swore in special constables, directed or led troops at the scene of a disturbance, pleaded with the Home Office for more troops, and perhaps played a leading role in forming a militia company which later could be used as a kind of substitute police if the need arose. Therefore, the availability of one or more active Justices of the Peace should have made a substantial difference in the overall rate of repression within a given region. The term "active Justice of the Peace" appeared frequently in Home Office correspondence, where it meant a Justice who was willing to assume the responsibilities of his office and to play an active role in carrying out Home Office policy with regard to the suppression of disturbances and other matters. Many Justices of the Peace were not willing to do this. Attendance at the quarter sessions had little to do with day to day availability of a Justice since the Court's meetings tended to be events of great social importance in the county and were often attended for that reason alone. As a measure of activity in the sense meant by the Home Office, and here, we may look to regular performance of routine responsibilities at petty sessions. Some twenty-four Justices of the Peace of Lancashire attended three or more petty sessions in 1800 and thirty-four in 1816 . Using atten-

30. 53 Geo. III c.72.

31. Midwinter, Law and Order in Early Victorian Lancashire, passim. 


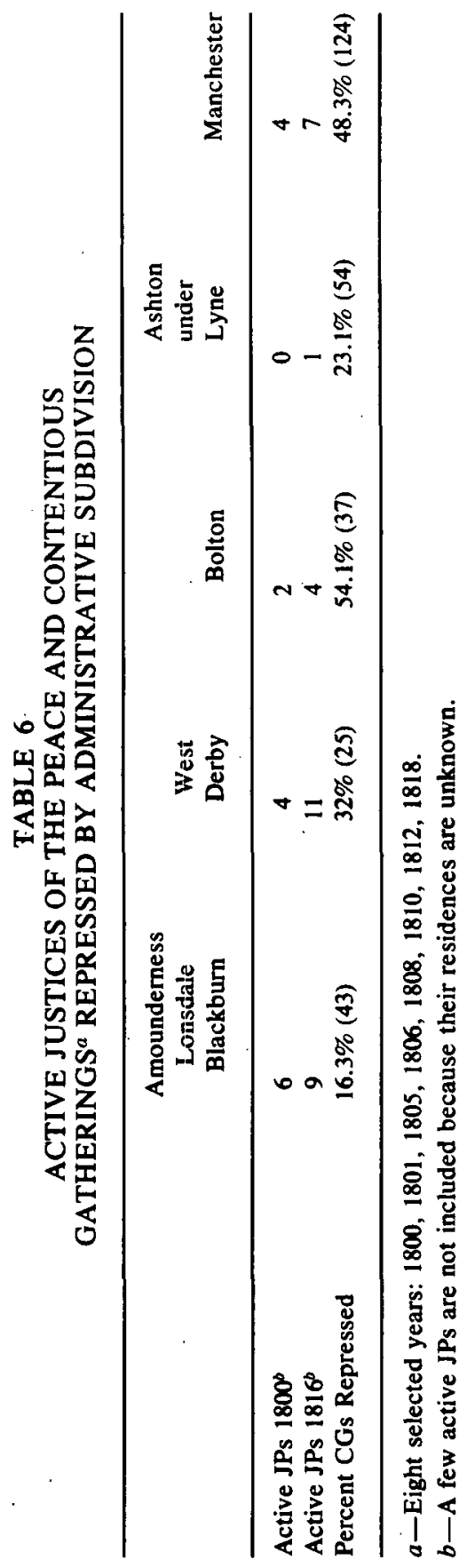


dance at three or more petty sessions as a definition of "active," Table 6 shows that gatherings in regions without active Justices of the Peace experienced a much lower rate of repression. Bolton and Manchester Divisions of the quarter sessions had very active Justices who were available for mobilization and in the city on a regular basis. These regions had the highest overall rates of repression. The regions encompassed by Lonsdale, Amounderness, Blackburn, and West Derby hundreds were considerably more rural than the region surrounding Manchester and Bolton. Although active Justices resided there, the Justices lived on rural estates some distance from the centers of population, and the rate of repression is much lower in these areas. The Division of Ashton under Lyne experienced a low rate of repression, according to the data presented in the preceding section, although it was populous and in many respects resembled the divisions of Bolton and Manchester. Table 6 shows that it was least well supervised by Justices of the Peace. In the first decade of the nineteenth century, no Justice lived in or near Oldham and was available on a regular basis, although occasionally justices who lived in nearby Yorkshire sat at Oldham or Ashton. The absence of a Justice also affected the availability of specially deputized citizens or special constables, during disturbances in each region. Justices of the Peace administered the oath of office to the special constables. While special constables appeared in twenty-seven percent of the contentious gatherings involving violence in Manchester and in about nineteen percent under Bolton Division, they appear in only four percent in Ashton under Lyne Division. All other policing forces, the military cavalry, and infantry, and the militia also appeared less frequently in Ashton under Lyne Division than in other divisions.

We have examined the effects of substantial constraints on the capacity for repression. When constables, militia, military and Justices of the Peace were unavailable, suppression did not take place. One important result is that the social history of an entire region could be affected by variations in the structure of authority such as those described here. Bolton and Manchester were natural gathering points and places for the formation of working class associations because of their importance as centers of employment and as locations of visible conflict with employers and others. Yet both towns had active magistrates. The centers of working class political activism before 1820 lay in the Ashton under Lyne-Oldham region which contained many growing working class villages and relatively few active authorities. ${ }^{32}$ As concentration of factories in and around

32. An excellent study of the absence of law enforcement in Oldham on early nineteenth century radicalism in that town is available in Foster, Class Struggle in the Industrial Revolution. 
a few large towns in the southeast continued, however, collective action was brought more and more under the supervision of better organized police forces. One result was that massive violence against machinery and food suppliers occurred less frequently. A second result was that new forms of collective action took their places. Demonstrations, factory pickets, and an increased interest in participating in Parliamentary and local political process became the dominant forms of working class collective action. Thus, variations in the capacity for suppression of collective action play an important role in the forms and development of political and economic conflict.

\section{Repression and the Law}

Justices of the Peace possessed broad authority to repress gatherings. Authority to act is never, by itself, a sufficient description of the reasons for acting. The decision to exercise authority in a particular instance is a product of at least three factors: organizational constraints, sanctions for inaction, and the official's motivation to take action. Of these, sanctions by other authorities were perhaps the least significant for the Lancashire Justices of the Peace. While the Justices authority was subordinant to that of higher courts and Home Office Officials higher authorities rarely intervened. Even when the Home Office held sufficient leverage to compel or limit action, the understandings between the Home Office and the Justices frequently did not depend on legal definitions of proscribed behavior at all. In fact, Justices of the Peace usually had little training in law and, other than the clerk of the Peace who was a lawyer who advised the Justices on court-related matters, little technical assistance in interpreting the law. The Justices of the Peace were not lawless, but the importance of authoritative definitions of proscribed collective action depended on the uses the Justices desired, and to a lesser extent were required, to make of them.

Notwithstanding this apparent freedom to act the Lancashire data show that legal change could affect the rate of repression. The rate of repression of combinations dropped by nearly fifty percent following the liberalization of the laws prohibiting combinations in 1824-25. But the reasons for the change in the rate of repression, and the effects of the change merit closer attention. First, for contrast, even though laws prohibiting peaceful assemblies to express grievances existed in 1800,1801 and 1818 , the rate of repression of such assemblies did not jump in these years. Nor did the new laws against specific types of collective violence in $1800,1801,1802,1819$ produce unusual rates of repression. Clearly under some circumstances changes in the law may not affect the behavior of authorities. However, the Combination Acts increased the capacity for suppression in two ways (while the other laws did not). First, an employer could 
initiate prosecution under the Combination Acts at a petty session. Thus a new class of persons was added to the "police" forces of the county. Secondly, by making offenses under the Acts triable at petty sessions, the risk of a reversal by a jury was avoided. Further, with prosecution placed in the hands of employers, Justices of the Peace lost their discretion to repress. They might not convict (an option rarely elected), but they were required to try the employees accused of forming a combination. Thus the increased rate of repression after the passage of the Acts is less surprising in view of the way the Acts changed the procedures for obtaining a conviction.

While the enforcement of the Combination Acts accounted for a large part of the high rate of repression of combinations between 1800 and 1824 , the effects of enforcement were blunted by the role played by Justices of the Peace themselves. First, many of the petty sessions convictions were overturned on procedural grounds on appeal before the full Quarter Sessions. To the Justices acting in their judicial capacity the "rule of law" meant something quite different from the effectuation of Parliamentary priorities. Secondly, while some Justices of the Peace saw little difference between combining to raise wages and sedition, many Justices of the Peace kept a great distance from the disputes between workers and employers. The correspondence of a Manchester Justice of the Peace during the strikes of 1818 reveals some of the reasons for the leniency thus shown collective action by workers. James Norris wrote to the Home Office in July, 1818: ${ }^{33}$

(The Dyers) adopted the practive for the first time here of parading two and two through the public streets almost every daycertainly conducting themselves with great order, but still the practice being novel, it tended to alarm. My brother magistrates and myself did not think it right on this account to interfere in their practice in order that the lower classes might see distinctly that we kept aloof from any question between them and their employers ... as to the advance of wages, and in order that they might pay a greater respect to any judgment which we might be called upon to pronounce in case the master proceeded against any of them under the Combination Act.

Thus while enactment of the Combination Act of 1800 produced a dramatic change in the repression experienced by combinations, the enforcement and effects of the Act were the products of more than the expansion of the scope of the authority possessed by the Justices of the Peace.

33. Norris to Sidmouth, 29 July, 1818. H.O. 42/178. 


\section{Political conflict and law enforcement}

In Lancashire, in some years suppression of political gatherings was greater than suppression of other gatherings. In other years, political gatherings were treated as other gatherings were or more leniently. As a first hypothesis, we might argue that the increased rate of repression occurred as a result of new legislation. The French Revolution brought war (declared in 1793) and political reaction. The political reaction of the war years affected the English establishment and its view of working class collective action. Between 1793 and 1820 more than sixty acts directed at repression of working class collective action were enacted by Parliament. Between 1793 and 1800 statutes were enacted which proscribed virtually every form of working class collective action. ${ }^{34}$ Parliament enacted a similar legislation in spurts during the period of massive "Luddite" disturbances in 1811-1812 and again during the working class political movement between 1817 and 1819.35. Two of these periods, 18001801 and 1812, correspond with increased repression of political gatherings.

Some of the legislation in force in 1800 and 1801 did increase the capacity of the Justices of the P'eace and was used. For example, the Unlawful Oaths Act of 1797 provided spies employed by the Lancashire Justices of the Peace with a broad license to accuse. The spies were employed to penetrate alleged seditious organizations among the working classes. Spies and informers, with the aid of the Act, could place a victim in danger of transportation merely by claiming he had sworn an oath for a mutinous or seditious purpose or had sworn to obey a leader not having authority by law for that purpose. $^{36}$

The Unlawful Oaths Act boosted the effectiveness of a poorly supervised spy network and made it unnecessary for the weak police force to catch revolutionaries in some breach of the peace, or even engaged in a political act of any sort whatsoever. Members of an alleged group of United Englishmen were caught in this manner by a Bolton Justice in 1801 and one was hanged for treason. Further, the Seditious Meetings Act was used freely to suppress any unlicensed meeting which the Justices supposed to be for the purposes proscribed by the act. Whatever their impact on the rate of repression of

34. See notes 18 and 19 , supra.

35. In 1812 Parliament added the requirement that dissenters' meeting houses be licensed. 52 Geo. III, c.7 (1796). In 1817 Parliament suspended the Writ of Habeas Corpus and made political meetings licensable once again. $57 \mathrm{Geo}$. III, c.3; 57 Geo. III, c.19. In 1820, Parliament passed the infamous "Six Acts" in response to the massive meeting at St. Peter's Fields near Manchester in Lancashire. $60 \mathrm{Geo}$. III, c. $1,2,4,6,8,9$.

36. 37 Geo. III, c. 123 . 
political gatherings neither of these pieces of legislation was in effect in 1812.

Other legislation in force in 1800-1801 reduced the accountability of authorities after arrests had been made. Thus the power to issue ex officio informations and the suspension of the Writ of Habeas Corpus both had the effect of making it possible for authorities to ignore sanctions which might otherwise make arrests look improper. Such considerations were a major factor in determining the adherence to rules of law by Justices of the Peace. On this point, no communication is more instructive than that of the Reverend W. R. Hay of the Manchester Division of the Lancashire quarter sessions in 1801 . Hay was a rabid opponent of working class mobilization and feared the worst at every indication of unrest. Hay and another similarly disposed Justice in 1800 and 1801 suppressed the great popular meetings on the Lancashire-Yorkshire border which their spies had informed them were discussing revolutionary designs. A letter from Hay to the Home Secretary written at the height of the repression illuminates the importance of the sanctioning power of other roles in the process of law enforcement, ${ }^{37}$

I want to explain why we were content to prevent any meeting to an effective purpose rather than hold prisoners. Actually we had no precise information of the objective of the meeting. All the information I had was that a very numerous one for some purpose or other would take place on Sunday at Buckton and that handbills had been distributed. But in the absence of any specific information as to the purpose of it, any numerous meeting on Sunday was not to be suffered to take place if it could be prevented.

Arriving at the meeting with a copy of the expired Seditious Meetings Act of 1795 in hand Hay found the meeting peaceful and civil. Not daunted by the absence of grounds for reading the Act, Hay wrote,

... we . . . thought it best to presume that the meeting was intended for seditious purposes and taking a chance that the procedure under the new act was the same as that under the 36th Geo. III ordered that to be read, and the people were dispersed.

Hay referred to the Seditious Meeting Act which had expired in 1799 and was being considered by Parliament for renewal. No one was arrested because Hay guessed, "we might possibly be under difficultites if we should afterwards in a court of Justice be called upon to prove the object of the meeting to be seditious." Hay's candor reveals that to him upholding the law consisted of adherence to something other than the letter of the law. Removal of procedural

37. Hay to H.O. May 13,1801 . H.O. $42 / 62$. 
constraints on someone such as Hay, therefore, might be a significant factor in increasing the scope of repression.

Notwithstanding these effects of the 1794-1801 legislation, there are sound reasons for arguing that the existence of new legislation alone does not explain increased repression of political gatherings in all three periods. First, the legislation available in 1800 and 1801 , and which may have had significant impact in those years, was not available in 1812 . Secondly, much of it was passed after the acts which were repressed. The Riot Act remained the main weapon in the Justices' arsenal. Further, much of the legislation did not define political gatherings as special targets of repression. Thus political gatherings became a special target of repression for other reasons.

Hay's explanation of his behavior at Buckton in 1801 is of considerable help in understanding what was different about 1800-1801 and 1812. His acknowledgment that he could be called to account for an arbitrary official act, although he was unembarrassed by this admission to the Home Office, is key. Throughout the period of the early nineteenth century, the handling of domestic peace keeping became entangled with conflicts arising from the rapidly changing political structure of England. The period between 1780 and 1832 saw the steady rise in influence and political aspirations of a broad and growing commercial class. At a national level this class was at odds with landed gentry of the county over the war with France because the war closed continental ports and markets, over the Corn Laws because the laws raised the price of food and therefore increased the price of labor, and over extension of the Parliamentary franchise. Locally, and in Manchester in particular, the wealthier commercial interests were excluded from the Tory establishment which controlled the manorial offices, the police office (under the Improvement Act), and the parish vestry. Thus on the issues of political reform and cheap food, the commercial class often found an ally in the working classes. On the issues of opposition to basic constitutional change and cheap labor, the landed gentry and the wealthier elements of the commercial class had much in common. The rising commercial class served on Lancashire's petit juries and on grand juries. Thus part of Hay's concern for being called to account is based on the unpredictability of the reaction of a jury comprised of lesser members of the community than himself, members of the community who, at times showed considerable sympathy for the working classes.

In each of the three periods of high legislative activity, Parliament formed a committee of secrecy in each House to examine the evidence of revolutionary activity much of it from Lancashire spies. In each period, both the legislation and the work of the committees reflect the degree of unity in opposition to political threat from within. By contrast, the one war period of great unrest for which a negative correlation between political objectives and repression exists, 1808 , is a period of substantial opposition by the commercial 
classes to the policies of the enfranchised elite with regard to continuing the war with France, the corn laws and other matters affecting commerce. In Lancashire, 1808 is the year in which the middle class movement for Parliamentary reform revived. ${ }^{38}$

Thus, among the factors which affected the rate of repression of gatherings, a widespread agreement among groups with some control over use of legal resources for repression on the degree of threat posed by a particular form of collective action appears to have been significant. In England, between 1800 and 1830, the period of our study, the mounting conflict between enfranchised elite and rising commercial class, and the growing class conflict between commercial class and workers resulted in swings in the pattern of repression as the emerging owners of industry alternated between defending the political system which was slowly giving them power and keeping the means of political opposition unrestricted and available.

\section{Repression and the Rule of Law}

We have characterized management of contentions gatherings in Lancashire by the Justices of the Peace prior to the French Revolution as paternalistic and lenient. The fact that eighteenth century collective action was typically the product of relatively short term food or price dislocations, typically protected a traditional price or source of supply, and could rarely be suppressed by brute force suited a paternalistic and lenient style of law enforcement. Manipulation of sanctions for crime in the eighteenth century to show leniency, argues Douglas Hay, produced deference among the ruled population, which became more inclined to accept the legitimacy of governance by the ruling classes. Lenient handling of disturbances might have had similar objectives and a similar effect.

By 1830 , the conditions which made the creation of deference possible through the manipulation of leniency in handling contentious gatherings had changed. Conflicts which gave rise to gatherings had become relatively long term, and the objectives of the working classes were no longer compatible with the social order of which the Justices of the Peace were a part. In very broad terms, the rise of a capitalist economy meant that the focus of collective action shifted away from food supply to working conditions, and then, stimulated by the occurrences of 1789 and the English reaction, to political ends. New groups of workers defined not by community membership but by interest protested about problems which were not short term. Members of the working classes now wanted what was incompatible with the order of things of which the Justices of the Peace were a part: higher wages, an end to corrupt government, repeal of the corn laws, and Parliamentary reform.

38. Marshall, The Development of Public Opinion in Manchester, 1780-1820, p. $131 \mathrm{pp}$. 
As a parallel trend, repression became more effective. The fact that more contentious gatherings took place in towns meant they could be suppressed more easily. In the nineteenth century towns began to establish regular police forces. Further, the means by which persons assembled to discuss and act upon these new interests were more vulnerable than the means by which persons assembled for an eighteenth century food riot. The more people a focused interest group attempted to organize, the more vulnerable it was to arrest of its leaders, to seizure of its treasury, and even to cooptation by middle class dissidents or government agents provocateurs. The combined changes completely transformed the basis upon which paternalistic crowd management was based. As the nineteenth century progressed repression took place in a context of long term conflicts and claims, demands which included changing the traditional social order, and increasingly effective repression.

Under these changed circumstances how was the relationship between repression and the rule of law changed? Since protest was increasingly long term and directed at the very roots of the society upon which the traditional social position of the Justices of the Peace depended, leniency was a less appropriate alternative. Deference could not be expected in return for leniency because the recognition of class interest by the working classes meant that there were no paternalistic relations to restore. As the Justices played a smaller and smaller part in the selection of targets and the directing of the police, crowds were repressed by police which lacked the Justices' broad discretion and which lacked the authoritative stature of the Justices. All of these changes meant that manipulation at the point of repression was less possible and less fruitful. Yet to suggest on the one hand that repression became a matter of brute force applied at will or to suggest on the other hand that the rule of law no longer played a powerful symbolic role in producing obedience to authority is simply inaccurate.

The reasons for restraint by authorities must be sought in circumstances other than those which produced leniency and deference in the eighteenth century. Two sources of self-restraint are apparent from the Lancashire study. The first, illustrated by W. R. Hay's confession of uncertainty about the legality of his suppression of the Buckton meeting, represents a source not discussed at all by Douglas Hay, i.e., the structure of the system of law enforcement. The second, illustrated by James Norris' conscious manipulation of judicial authority, represents a form of manipulation similar to the leniency described by Douglas Hay and which, presumably, could occur in any law enforcement system whether or not it was embedded in eighteenth century paternalistic, landed society.

Whatever the content of the "rule of law" as an abstract ideal, the Justices of the Peace lived with the conscious and often articulated knowledge that adherence to principle was compelled by circumstance and subject to some degree of manipulation. What those 
circumstances were can best be learned from the Justices who enforced the law. W. R. Hay's correspondence with the Home Office in 1801 acknowledged that the law was a practical constraint on his behavior. No doubt Hay thought of himself as one who upheld the law. He felt compelled to inform the Home Secretary that he had read the proclamation of the Seditious Meetings Act. He viewed manipulation of the law as consistent with his authority though not necessarily consistent with the law. He was not free to do more only because legal procedures might force acknowledgement of his illegal manipulation at a later date. In his recognition of this constraint lies acknowledgement that persons who controlled other aspects of the legal process might not support him in his actions. Why he would not be supported again is linked to both practical and ideological constraints. English legal procedure normally called for segmented control by various strata within the upper classes. Crown prosecutors, Whig members of the Manchester Bench (Hay was a Tory), a grand jury of large land holders, and perhaps a petit jury of lesser property holders or members of the growing commercial class might all be asked to pass judgment upon his actions at different stages of the legal process. Hay could not count on the support of each of these groups absent extraordinary circumstances producing an atypical unity of opinion among them. Their dissatisfaction with Hay's actions would be expressed in terms of legal doctrine (for example the grand jury might return "no bill" for want of authority to arrest participants) but deeper motives for the lack of support lay in the differences of outlook among these factions. As it happened, at the trial of persons arrested for participating in related events in 1801, the grand and petit juries of Lancashire amply supported their Justices of the Peace indicating both that Hay's fears were perhaps unfounded and that the countervailing opinions of others involved in the legal process which might compel leniency at other times did not do so in this case.

Thus, the rule of law was a practical constraint. Under circumstances in which authorities wished to manipulate legal sanctions to produce more severe results, the pattern established throughout the eighteenth and nineteenth centuries was to concentrate control over the legal process by eliminating the functions of some of the constituencies which were least reliable. Douglas Hay notes the increase in the petty sessions jurisdiction of the Justices of the Peace in the eighteenth century. This trend continued in the period of industrialization and political conflict after 1789. The Combination Acts were enforced at petty sessions. Further, the suspension of the Writ of Habeas Corpus in 1794 and 1817, the authorization of $e x$ officio informations in seditious libel cases (which, therefore, did not require a grand jury), and other procedural changes all had the effect of removing the constraints of the rule of law. Such measures could only be temporary under the political conditions of the time because they were too threatening, like the 
creation of a standing army or a permanent police force, to powerful political interests. The opposition of such interests to constraints on "civil liberty" or legal process need not have anything to do with either sympathy for working class protest or abstract adherence to the rule of law.

The second source of restraint was the opportunity for leniency provided by Parliamentary regulation of conflict between employers and employees. James Norris' desire to appear neutral in conflicts between masters and workmen can be understood from several perspectives. First, neutrality suited the traditional paternalism of the Justices. As the Justices were in the case of an eighteenth century food riot, Norris was in some sense, above the conflict between workers and employers. Here the role played by the Justices of the Peace under the Combination Act was one assigned explicitly by the Act, not a role based primarily on social rank. Norris acknowledged pressure to conform to that role. The pressure he acknowledged came from the need to maintain the dyers' belief in the legitimacy of the Justices' role under the Act. For the sake of maintaining their belief in the Justice's legitimacy, Norris refused to interfere with collective action which could quite easily have been construed to have been a breach in the peace. From a second perspective the orderliness of the demonstrations of the dyers created its own protection. Like the protest of the eighteenth century (if we take the food riot as typical) the dyers' demonstration made clear that its target was limited and did not include dissatisfactions with the social order which encompassed their place or that of the Justices. Instead of achieving this recognition through the kind of claim they were making (as food rioters did) they achieved it through the form of their protest, the very vulnerability and peacefulness of which was compatible with the limited, non-violent nature of the economic struggle in which the Justices had little personal stake. As the nineteenth century progressed, this leniency toward demonstrations of workers by Justices of the Peace did not continue, since authorities became more identified with employers as the commercial classes gained political control of local government.

The sources of restraint which these cases illustrate must not be confused with full fledged "legality" as that term is understood in legal ideology. ${ }^{39}$ What we have discovered are practical, often manipulatable, contingencies which set limits on the behavior of Justices of the Peace. The limits were accepted sometimes with full knowledge that they tended to make the Justices' actions appear more legitimate; at other times, the limits were accepted without any concern for popular legitimacy, but in acknowledgement that the

39. By full-fledged "legality" I mean the ideal of a self-restraining system commited to the reduction of arbitrariness in the use of authority and to a legal order founded in reason. See P. Selznick, Law. Society and Industrial Justice (New York: Russell Sage, 1969), pp. 11-18; L. L. Fuller, The Morality of Law (New Haven: Yale University Press, 1964), Chapter II. 
acceptability of behavior to other authorities creates significant restraints. Other than these sources of restraint, these data do not show that the rule of law created any limits on the use of legal authority at all.

\section{Conclusion}

This study has sketched the impact of social change in Lancashire on the repression of popular contentious gatherings. The data suggest that repression was severely restricted by the weaknesses in the means of policing the county. The industrialization of Lancashire created new opportunities for collective action and new grievances, but at the same time aided enforcement in some ways while making it more difficult in others. Cities became better policed, the countryside a refuge for popular gatherings. The changing appearance of crowds, in terms of both size and objectives created circumstances with which the traditional authorities of the county were not familiar. Reactions to large, hostile popular gatherings showed that the Lancashire Justices felt that force and not leniency was the safest means of ruling the county. Nevertheless, force could not be applied at will. Resistance to unlimited use of force was generated by legal institutions themselves and lack of police or troops circumscribed the power of Justices of the Peace.

On the interesting question of what constraints legal institutions placed on repression, this study tends to show that repression of popular gatherings was manipulated by authorities in both the eighteenth and nineteenth century for reasons of strategy and in recognition of constraints created by legal "ideology." I have argued that the constraints were often practical, however abstract the principles in whose name they appeared. I have suggested that the temperance which instilled a belief in the justice of the legal system was in part an effect of the divided rule among factions of the ruling class reflected in the segmentation of English legal procedure. I have argued that except in extreme circumstances of ruling-class unity, the legal system possessed the capacity for moderating the excesses of individual Justices. In the nineteenth century, the opportunities for paternalistic manipulation of the legal system seem to have been fewer than in the eighteenth, but where circumstances suited displaying leniency in order to strengthen the legitimacy of authority it seems to have been so employed.

In the end restraints on repression were practical for the ruling class in two senses. Restraints preserved ruling class political liberties as well as the hegemony of ideas about justice. There is little in these findings which suggests that law was a source of moral restraint among authorities, but it appears with some certainty that legal institutions enmeshed the exercise of power in ways which are both complex and class-oriented. 